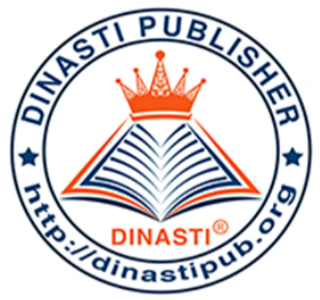

\title{
IMPLEMENTATION OF BLUE OCEAN STRATEGY (BOS) AT PT. ANEKA DIGITAL SUKSESINDO IN THE EFFORT TO INCREASE THE COMPETITIVE ADVANTAGE AGAINST THE COMPETITORS
}

\author{
Acep Andi Suhendi ${ }^{1)}$ \\ ${ }^{1)}$ Universitas Mercu Buana, Jakarta, Indonesia
}

\begin{tabular}{|c|l|}
\hline $\begin{array}{c}\text { ARTICLE } \\
\text { INFORMATION } \\
\text { Received: } 22^{\text {nd }} \text { May } 2020 \\
\text { Revised: } 20^{\text {th }} \text { June } 2020 \\
\text { Issued: } 30^{\text {th }} \text { July } 2020\end{array}$ & $\begin{array}{l}\text { Abstract: The increasing competition in the } \\
\text { business world requires a company to always make } \\
\text { transformation not only to meet the company's } \\
\text { targets but also for business sustainability or } \\
\text { survival. The similar thing happened with PT.Aneka } \\
\text { Digital Suksesindo which is one of the PMA } \\
\text { (Foreign Investment Company) from China which } \\
\text { is engaged in the distribution of electronic products } \\
\text { made in China which is always innovating in order } \\
\text { to maintain its existence in Indonesia. Some of its } \\
\text { auperior products are 1. Black Shark which is } \\
\text { mobile gaming that offers maximum performance. } \\
\text { It is a smart phone which is able to hold on for } \\
\text { hours to play games and fast charging, 2. Amazfit } \\
\text { Smartwatch is a smart watch from Xiaomi that can } \\
\text { be used to monitor heart rate, real GPS time to } \\
\text { acepandisukses@yahoo.com } \\
\text { aims to explain the implementation of the Blue } \\
\text { Ocean Strategy in an effort to improve competitive } \\
\text { advantage and also to determine the conditions of } \\
\text { the internal and external environment through } \\
\text { SWOT Analysis, namely Strength, Weakness, } \\
\text { Opportunity, Threat (Threat) at PT. Aneka Digital } \\
\text { Suksesindo. Based on the type of research that is } \\
\text { descriptive research using a qualitative approach } \\
\text { Keywords: Strategy, Blue Ocean Strategy, SWOT } \\
\text { Analysis, Competitive Advantage }\end{array}$ \\
\hline
\end{tabular}

\section{INTRODUCTION}

Indonesia is one of the markets having electronic sales (e-commerce) growing rapidly. Since 2014, Euromonitor, an independent market research service provider, has recorded online sales in the country of US \$ 1.1 billion. In addition, based on data from the Central Statistics Agency (BPS) it is known that the Indonesian e-commerce 
industry in the last 10 years increased by $17 \%$ with a total number of businesses reaching 26.2 million units. In addition, based on research data released by Google recorded in the 2018 SEA e-Conomy report, that the value of Indonesia's digital economy in 2018 reached US \$ 27 billion or around Rp391 trillion, growing or increasing percentage to $500 \%$ from 2014.

With the above electronic trading conditions, PT.Aneka Digital Suksesindo has enlivened the competition by becoming one of the official distributors of Indonesian e-commerce industry products.

The rapid competition that is very felt requires companies to try to develop new and more effective strategies. In this case the Blue Ocean Strategy (BOS), which is a clean market structure without fierce competition, so that its existence is very important given the increasingly fierce business competition. Blue Ocean Strategy (BOS) through a framework and analytical tool, along with six principles, is a way out of a market that is starting to narrow and turning to new ones where companies can avoid fierce competition.

PT.Aneka Digital Suksesindo is one of the business people and also a player in the e-commerce industry, able to read opportunities from several factors that exist in Indonesia, one of which is the current lifestyle that uses a lot of electronic goods, especially smartphones and smartwatch.

Analysis from the Blue Ocean Strategy (BOS) helps PT.Aneka Digital Suksesindo know the existing competition map and it can be used as a benchmark of how much value or utility that PT.Aneka Digital Suksesindo can provide to consumers.

Based on the foregoing, a study was conducted with the aim to find out and explain the internal and external environment through SWOT Analysis, and how the implementation of Blue Ocean Strategy (BOS) at PT.Aneka Digital Suksesindo.

\section{LITERATURE REVIEW \\ Strategic Management}

David (2010: 5) states that strategic management is an art and knowledge in formulating, implementing, and evaluating cross-functional decisions that enable organizations to achieve their goals. Hunger and Wheleen (2003: 9) suggest that there is a basic element in the strategic management process that starts from environmental observation, strategy formulation, strategy implementation, and evaluation and control. Business companies have three levels of strategy as stated by Hunger and Wheleen (2003: 24), namely the corporate level strategy, which is a strategy that is formulated to be comprehensive and aims at the welfare of the entire organization with multidimensional tasks, business level strategy which is developed at the division level and emphasizes improvement competitive position of products or services, and functional levels whose strategies emphasize maximizing resource productivity.

\section{Blue Ocean Strategy (BOS)}

Blue Ocean Strategy (BOS) is one of the strategies to win the market by bringing new insights from different perspectives. The new understanding serves as a guideline for determining strategies to leap over industry boundaries that have been rigid. Blue Ocean Strategy (BOS) has one of the characteristics that is in the form of value innovation that distinguishes it from the Red Ocean Strategy. Kim and Mauborgne (2006: 36) state that value innovation is created related to and influences the cost structure and the value offer for buyers. Value innovation is a combination of 
efforts to increase buyer utility factors and reduce cost factors at the same time, without focusing on making trade-offs (exchanges) on one of the factors.

\section{SWOT Analysis}

According to Elyarni (2016), to face market competition, especially in dealing with global markets, a company must be able to establish the SWOT method as the basis for formulating strategies to increase the value of competitiveness for its products.

SWOT analysis (SWOT analysis) includes efforts to identify strengths, weaknesses, opportunities, and threats in relation to company performance. External information about opportunities and threats can be obtained in many sources, including customers, government documents, suppliers, banks, partners in other companies. Many companies use the services of scanning agencies to obtain newspaper clippings, internet research, and analysis of domestic trends and relevant global trends (Richard L. Daft 2010: 253).

Istiyanto (2019) also stated the reason why it is necessary to apply this SWOT analysis in determining the company's strategy, because a company must try to win a competition or business competition through strategic means. It is trying to win competition from opponents or business competitors, in order to continue to lead in business position in similar industry competition. The aim is none other than to be able to dominate the market and reach a strategic position in business competition with competitors. In addition, to be able to compile and make business decisions after previously observing and analyzing the strengths and weaknesses of both the company itself and competitors, while at the same time protecting the company's internal from interference or threats that may come from competitors or competitors.

The elements of SWOT analysis include:

\section{Strength (Strength)}

Analysis of the elements of strength or excellence is owned by the company. For example, analyzing the advantages or advantages of the company in terms of technology, quality of production, strategic location, or other elements of strength that emphasize the company's excellence. Usually in a SWOT analysis the company focuses on making as many strength as possible as a competitive effort.

\section{Weakness}

In addition to seeing the company's strengths, it is very important to know the weaknesses or weaknesses that the company has. To find out the weaknesses of the company can be done by comparing with competitors, for example by analyzing things that other companies have but do not have your company. If you want to make a list of company weaknesses more objectively, you can also dig consumer testimonials about the weaknesses or weaknesses found from the company.

\section{Opportunity}

The opportunity element is generally formed at the beginning of building a business. This is because businesses are formed based on opportunities or opportunities to make profits. In addition, opportunities can also include new opportunities that are open for future business development, such as new market share and current market growth. 
4. Threats

Analysis of the element of threat is very important because it determines whether the business can survive or not going forward. Some of which include threats are the number of competitors, the availability of resources, the duration of consumer interest, and so forth.

\section{Competitive Advantage}

Sampurno (2010: 155) explains that competitive advantage refers to the existence of company resources. Company resources include physical assets, intangible resources or capabilities.

Whereas Craven (1999: 18) states that a company's competitive advantage can be achieved by providing more value to consumers through lower prices than competitors with the same or no less benefits, and characteristics of benefits that can cover high or higher prices.

\section{RESEARCH METHODS}

The type of research in this study is descriptive using a qualitative approach. The purpose of descriptive studies according to Sekaran (2007: 159) is to give researchers a history or to describe aspects relevant to the phenomenon of attention from the perspective of a person, organization, industry orientation, or others. While Indriantoro and Supomo (2009: 26) argue that descriptive research is a study of problems in the form of current facts of a population.

\section{RESULTS AND DISCUSSION}

\section{SWOT Analysis}

The SWOT analysis in this study is used as supporting data in creating a Framework in Blue Ocean Strategy (BOS). Here are the results:

- Strength

Prices are below market prices because they are one of the official distributors of Black Shark and Xiomi products

- Weakness

There are still shipping orders that exceed the target

- Opportunity

Public interest in smart phone gaming is very high

- Threats

The existence of a black market or sale of illegal products on the market

\section{Implementation of Analysis Tools and Frameworks Four-Step Framework}

The four-step framework aims to design strategies for creating value innovations and low costs can be achieved simultaneously. There are four basic questions in forming the Four Step Framework:

1. What factors must be eliminated?

2. What factors should be reduced? 
3. What factors must be improved?

4. What factors have not been offered by competitors so they must be created?

PT.Aneka Digital Suksesindo answers these basic questions, namely:

1. Eliminating the competitive factor in the form of an expensive impression on the products sold by providing understanding or explanation to consumers that emphasizes the function and quality of the product.

2. Reducing aggressive promotional activities

3. Improving the delivery system.

4. PT. Aneka Digital Suksesindo, which is one of the official and legal distributors, so it is daring to provide not only a guarantee of replacement goods if the goods are received damaged but there is also cash back if the goods received exceed the time target specified in the delivery that makes a difference and has not given by competitors.

\section{Remove-Reduce-Enhance-Create (H-K-T-C) Scheme}

Here are the four steps at PT.Aneka Digital Suksesindo:

\begin{tabular}{|c|c|}
\hline Deleting & Improving \\
$\begin{array}{c}\text { The impression is expensive (giving an } \\
\text { explanation by emphasizing the function } \\
\text { and quality of the product on the } \\
\text { company's official website) }\end{array}$ & $\begin{array}{c}\text { Delivery system (in cooperation with the } \\
\text { shipping service) }\end{array}$ \\
\hline Reducing & Creating \\
$\begin{array}{c}\text { Reducing your own marketing / sales by } \\
\text { collaborating with Shopee, Tokopedia, } \\
\text { Blibli, Bukalapak, Lazada }\end{array}$ & $\begin{array}{c}\text { Give cash back if goods are received } \\
\text { exceeding the specified time target }\end{array}$ \\
\hline
\end{tabular}

\section{Implementation of Blue Ocean Strategy (BOS) Principles Reconstruct Market Restrictions}

The first principle has several steps called the Six Road Framework, which includes looking at alternative industries or other competitors in this case, for example, PT.Erajaya Swasembada and PT.Wiko Mobile Indonesia, which have already been players in the same industry with advantages as follows:

\begin{tabular}{|l|l|l|l|l|}
\hline $\begin{array}{l}\text { Name of } \\
\text { Competitor }\end{array}$ & Strength & Weakness & Opportunity & Threat \\
\hline $\begin{array}{l}\text { PT.Erajaya } \\
\text { Swasembada }\end{array}$ & $\begin{array}{l}\text { Widely } \\
\text { known } \\
\text { already }\end{array}$ & $\begin{array}{l}\text { Some products } \\
\text { have higher price }\end{array}$ & $\begin{array}{l}\text { The rate } \\
\text { purchasing of } \\
\text { smartphones } \\
\text { has never } \\
\text { dropped turun }\end{array}$ & $\begin{array}{l}\text { Emerging new } \\
\text { competitors }\end{array}$ \\
\hline $\begin{array}{l}\text { PT.Wiko } \\
\text { Mobile } \\
\text { Indonesia }\end{array}$ & $\begin{array}{l}\text { Widely } \\
\text { known } \\
\text { already }\end{array}$ & $\begin{array}{l}\text { Delivery } \\
\text { (sometime the } \\
\text { shipment exceeds } \\
\text { the target when } \\
\text { overloading) }\end{array}$ & $\begin{array}{l}\text { The rate of } \\
\text { purchasing of } \\
\text { smartphones } \\
\text { has never } \\
\text { dropped }\end{array}$ & $\begin{array}{l}\text { Emerging new } \\
\text { competitors }\end{array}$ \\
\hline
\end{tabular}


The second is to look at strategic groups in the industry, smart phone sellers who have differences in terms of price and quality of delivery but PT.Aneka Digital Suksesindo is able to cross these differences with lower prices and better delivery services.

The third step is to observe the chain of buyers of the smart phone industry.

The fourth step is to look at complementary product and service offerings because each product / service is influenced by the value of other products / services.

The Fifth Step is to look at emotional or functional attractiveness for buyers because sometimes competition can focus on the inherent attractiveness of products / services both emotional attractiveness such as feeling comfortable or satisfied, as well as functional appeal oriented to price, function, and product quality.

The Sixth Step or the last step is to look at momentum because products / services always have their respective trends. Three important principles in assessing trends across time include trends:

1. Has the essence of the company's business.

2. It cannot be reversed

3. Having a clear trajectory.

PT.Aneka Digital Suksesindo applied these three principles in relation to the smart phone industry so that it took steps to open several branches.

\section{Focus on the Big Picture Not on Numbers}

The second principle in this case is that the drafted strategy has a role in opening the focus of a broader perspective for the company. The strategy design has the advantage of showing competition factors, and competitors' strategic profiles. This is in accordance with what is meant by a focus on the big picture not on numbers, namely the report of each section as a material for evaluating performance and company targets to be achieved in the future.

\section{Reach beyond Existing Requests}

The third principle of the Blue Ocean Strategy (BOS) is against conventional logic or conventional strategies that segment consumers sharply, so that there are potentially unreachable potential customers.

Blue Ocean Strategy (BOS) groups several non-consumer criteria into several levels, each of which has the potential to be a consumer. Both those who have become consumers and non-consumers of PT.Aneka Digital Suksesindo certainly have differences, but also have similarities in the form of interest (interest) in quality products, affordable prices, and good service (delivery and warranty).

\section{Implementation of Strategy Correctly}

The fourth principle of Blue Ocean Strategy (BOS) contains an explanation of the strategic sequence. This series requires companies to understand how to make ideas according to the Blue Ocean Strategy (BOS). The main criteria in this strategic set are the existence of buyer utilities, affordable product prices and target cost achievement. These three criteria can certainly be fulfilled by PT. Aneka Digital Suksesindo. 


\section{Overcoming the Organizational Obstacles}

The fifth principle of Blue Ocean Strategy (BOS) has several steps consisting of removing cognitive barriers in the form of internal obstacles in an effort to awaken or give an understanding to all HR (employees) about what is the company's vision and mission. PT.Aneka Digital Suksesindo overcomes these obstacles by making clear company rules and work agreements for all Human Resources (employees) so that all Human Resources (employees) in PT.Aneka Digital Suksesindo understand it.

\section{Integrate Execution into Principle Strategies}

The sixth or the last principle of the Blue Ocean Strategy (BOS) is that it requires the company to build a culture of trust and commitment that motivates each HR (employee) to execute the agreed strategy. Making a culture of trust and motivation for HR (employees) can be realized through a fair process in implementing the strategy.

The three "E" principles of the Fair process of the Blue Ocean Strategy (BOS) are:

1. engagement (ie giving a clear role to each HR (employee)

2. explanation (explanation) that there must always be an explanation related to the achievement or target

3. expectation clarity (ie clear expectations) that is always setting goals both vision and clear and measurable mission is not something that cannot be achieved.

These three principles are interrelated with one another in the achievement of justice in the process of implementing strategy in the company carried out by PT. Aneka Digital Suksesindo.

\section{CONCLUSIONS AND RECOMMENDATIONS \\ Conclusion}

The implementation of Blue Ocean Strategy (BOS) at PT.Aneka Digital Suksesindo. reflected in the Erase-Reduce-Enhance-Reduce-Create Scheme and the stages of the six principles of Blue Ocean Strategy (BOS) carried out by PT. Aneka Digital Suksesindo allows PT. Aneka Digital Suksesindo to jump over market boundaries and open new markets that are different from conventional markets (which have existed).

\section{Suggestion}

The suggestions for PT.Aneka Digital Suksesindo as a place of research that is continuous evaluation needs to be done to determine the implementation of the strategies that have been made and to measure the extent of its success.

\section{REFERENCES}

Ali, Hapzi.2020.Modul Strategic Management Program Studi Magister Management.UMB.Jakarta.

David, Fred, R. (2006). Manajemen Strategis-Konsep. Edisi Sepuluh. Salemba Empat,Jakarta.

Elyami, R., Hermanto. 2016. Analisis SWOT Terhadap Strategi Pemasaran Layanan SAP Express pada PT. SAP. Jurnal Metris 17 (2016), 81-88

Kim, W. Chan dan Renee Mauborgne. 2005. Blue Ocean Strategy (Strategi Samudra 
Biru): Ciptakan Ruang Pasar tanpa Pesaing dan Biarkan Kompetisi Tak Lagi Relevan. Jakarta: Serambi.

Pearce II, John A. dan Robinson Richard B.Jr. (2008). Manajemen Strategis 10. Salemba Empat : Jakarta 